\title{
Simulation-based Methodology For Comparison Of nZEB Requirements In Different Countries Including Results Of Model Calibration Tests
}

\author{
Carsten Wemhoener ${ }^{1}$, Lukas Rominger ${ }^{1}$, Simon Buesser ${ }^{1}$, Mara Magni ${ }^{2}$, Fabian Ochs ${ }^{2}$, Christina \\ Betzold $^{3}$, Thomas Dippel ${ }^{4}$ \\ ${ }^{1}$ IET Institute for Energy Technology, University of Applied Sciences Rapperswil, Switzerland \\ ${ }^{2}$ Unit for Energy Efficient Building, UIBK, University of Innsbruck, Austria \\ ${ }^{3}$ Technische Hochschule Nuremberg Georg Simon Ohm, Nuremberg, Germany \\ ${ }^{4}$ TEB GmbH, Vaihingen/Enz, Germany
}

\begin{abstract}
With the implementation of the EU Energy Performance of Buildings Directive from January 1, 2019 on, the difference in national definitions of nZEB becomes evident. Due to different metrics, system boundaries and limits, it is hard to compare ambition levels of the new requirements of an nZEB in the different EU Member States. The assessment is even more complicated due to different national calculation methods and boundary conditions. In this paper a methodology is presented, which allows a relative comparison of ambition levels by the use of building simulation and a common reference building. The methodology is tested with different simulation programs in the countries Austria, Germany and Switzerland. Results confirm that the use of different standard simulation tools requires previous calibration of the reference building. Remaining limitations of the comparison for the case of different climate zones are addressed by defining a passive house in local climate as reference building with high ambition level, but this issue is also subject to further investigations.
\end{abstract}

\section{Introduction}

By January 1, 2019 all new public buildings in the EU have to comply with the nearly Zero Energy Building (nZEB) requirement according to the recast of the EU-Directive on the Energy Performance of Buildings (EPBD recast, 2010). Two years later by 2021 , this requirement is extended to all new buildings. In the EPBD, though, only an outline of what is understood by an nZEB is given, and the elaboration of the detailed definition and requirements of nZEB has been mandated to the EU Member States (MS). Despite different harmonisation initiatives, e.g. the collaboration of the Federation of European Heating, Ventilation and Air Conditioning Associations REHVA and the European standardisation organisation CEN to elaborate a common nZEB definition (Kurnitski et al. 2013) and a set of accompanying standards including the overarching standard EN ISO 52000-1 (2017), resulting nZEB definitions in the EU MS vary in metrics, system boundaries and limits. An overview of the different definitions is compiled in BPIE (2015), JRC (2016) and IPEEC (2018). This situation impedes a comparison of ambition levels, which are linked to the respective definition. A comparison gets even more complex due to the fact, that national boundary conditions and calculation methods are used to prove compliance with the national requirements, and climate data of the different sites across Europe also require different qualities of the building envelope and different efficiencies of the building technology to reach the same level of energy performance. In Ahmed et al. (2018), by the evaluation of an office building in the four European countries Estonia, Finland, France and Belgium it is concluded, that national boundary conditions have even a larger impact on energy performance than the change between Nordic and central European climate. Moreover, a higher primary energy requirement in the nZEB definition does not necessarily mean a higher energy performance due to the different boundary conditions and calculation methods.

The intension of the EPBD recast is to set higher objectives for building energy efficiency in order to decrease energy use in buildings and promote renewable production on the building site and nearby. However, by the different definitions and calculation methods, it is hard to judge the ambition level across the EU-MS. The ambition level denotes, how ambitious the national requirements are. This can be shown either relative to each other (by normalizing the boundary conditions such as the climate and internal gains, etc.) or with respect to a certain energy standard such as Passive House (PH) or net zero energy building (NZEB, see e.g. IEA SHC T52/EBC A40). In most countries, the NZEB balance refers to primary energy, but in this paper, absolute electrical energy input and the space heating demand are evaluated in order to avoid distortion by different national primary energy factors. For political legislation, a methodology to assess and compare the ambition level across EU-MS would be a means to promote better energy efficiency and higher shares of renewable energies in the EU building sector and can also serve to develop favourable system technology solution sets to comply with higher performance requirements. This would also facilitate the planning process and building technology manufactures could develop adequate system packages.

Annex 49 in the Heat Pumping Technologies (HPT) Technology Collaboration Program (TCP) of the International Energy Agency (IEA) entitled "Design and integration of heat pumps in nZEB" is dedicated to optimise heat pump application in nZEB. The eight countries AT, $\mathrm{BE}, \mathrm{CH}, \mathrm{DE}, \mathrm{NO}, \mathrm{SE}, \mathrm{UK}$ and the USA are collaborating on improved heat pumps in nZEB, which is also accompanied by monitoring projects in order to characterise the compliance with the nZEB balance in practical operation, evaluate the measured performance and identify optimisation potentials of integrated heat pumps in nZEB. 


\section{Method}

Based on the state-of-the-art analysis in Annex 49 a methodology is under development to assess and compare the ambition level in the participating countries.

\section{Reference building}

The methodology is based on building simulations with the different simulation programs Matlab-Simulink (2017), (two different model implementations) and TRNSYS 17 (2017). As reference building the so-called reference framework, which was introduced in Task 32 in the IEA Solar Heating and Cooling (SHC) program and further elaborated in the joint IEA SHC Task 44/HPP Annex 38 is used, since building parameters are well described in Dott et. al. (2013) and thereby offer a good basis for the modelling in the different simulation programs. The building itself is a single-family building depicted in Figure 1. For the application as nZEB reference building, the smaller, south-oriented roof area is additionally equipped with solar PV and different changes of the parameters of the building envelope and system technology parameters have been made. The building is further designed as "all electric building" and equipped with an air-to-water heat pump for space heating and DHW operation. Thus, electricity is the only delivered energy used for the building operation.

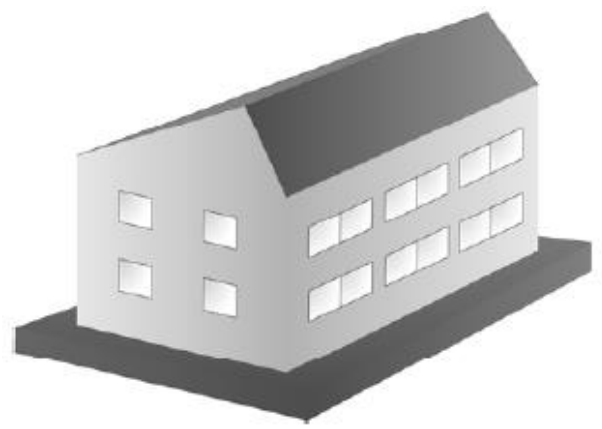

Figure 1: Reference framework building.

External dimensions are used for the calculation of the areas, which have been chosen to include thermal bridges. Therefore, with different insulation levels, the outside areas change. Since reference areas differ among member states, absolute values are used in this paper. In the framework document the reference building is evaluated in different climates and for different building envelope qualities. As basis for this methodology the Strasbourg weather with the highest envelope quality SFH15 has been chosen, which corresponds to a single family house with a heating demand in the range of $15 \mathrm{kWh} /\left(\mathrm{m}^{2} \mathrm{a}\right)$.

\section{Criteria}

The methodology itself consists of different steps, which are summarised in Table 1. During the steps different criteria of the building are varied. In the table changes from step to step are marked in bold and same parameters among the cases are colour coded in grey scales. Steps for the comparison of results are highlighted with the same colour in the column of the step number. In the following the different criteria contained in Table 1 are explained with the options denoted in brackets and separated by a slash.
- Tool (national/simulation) refers to the calculation method, where national refers to the national calculation tool for the approval of nZEB rating. As alternative, simulation programs are used in this investigation.

- Climate (framework/national [reference/site]) refers to the weather data as reference weather of Strasbourg of the framework or national weather. In some standards, national weather is distinguished in a reference site of the country and the weather of the actual building site.

- Boundary conditions (BC) (framework/national) denote the values of the domestic hot water (DHW) tapping profile, the internal gains distinguished in persons and gains of equipment/illumination as well as the set point of the indoor temperature. They can be set to framework and national.

- Envelope (framework/national reference/national) denotes the building envelope type. It can be set to the original framework envelope or it is adapted to the national requirement. In some countries, a national reference building is defined and requirements are set relative to the reference building. Thus, values correspond to framework, national reference or national for the building, which exactly meets the country's nZEB requirements.

- HVAC (framework/national) denotes the installed building system technology of the different systems like the ventilation (e.g. heat recovery rate/control/ volume flow), shading, heat pump, heat emission, heating and DHW control, auxiliary energy, storage etc. If there are prescription in the building regulation for the system technology these national requirements for the building system should be adapted for the national nZEB.

- Renewables (PV/solar thermal) denotes installed renewable energies, in particular solar PV. But also solar thermal or other renewables are an option.

\section{Steps of the methodology - Step 1: Calibration case}

Since different simulation programs have been applied, the first step denoted as "calibration case" consists of the modelling of the framework building in the different programs and compare simulation results for the common Strasbourg weather data. Comparison of simulated results is performed by monthly energy balances for the single energies of transmission and ventilation losses, solar and internal gains and the resulting heating demands. Furthermore, the monthly averaged operative temperature and regarding the system technology, the seasonal performance factor (SPF) of the heat pump in space heating and DHW operation and the yield of renewables are compared. Results were stepwise improved until presently good agreement is reached.

\section{Steps of the methodology - Step 2: Climate case}

Step 2 denoted as "climate case" does only consist of a simulation of the calibration case with change of the weather data to reference weather data of the respective country in order to evaluate the impact of climate data. Since currently only heating dominated climates of Austria, Germany and Switzerland are involved, differences are not so big. 
Table 1: Steps of the methodology to compare ambition levels

(italic, if a reference building is required in national building regulations).

\begin{tabular}{|c|c|c|c|c|c|c|c|}
\hline Step & Tool & Climate & $\mathbf{B C}$ & Envelope & HVAC & Renewables & Remark \\
\hline 1 & Simulation & Strasbourg & Framework & Framework & Framework & Framework & Calibration case \\
\hline 2 & Simulation & $\begin{array}{l}\text { National/ } \\
\text { Site }\end{array}$ & Framework & Framework & Framework & Framework & Climate case \\
\hline 3 & National & $\begin{array}{l}\text { Nationall } \\
\text { Site }\end{array}$ & National & $\begin{array}{l}\text { National } \\
\text { reference }\end{array}$ & $\begin{array}{l}\text { National } \\
\text { reference }\end{array}$ & $\begin{array}{l}\text { National } \\
\text { reference }\end{array}$ & $\begin{array}{c}\text { Nat. reference } \\
\text { building }\end{array}$ \\
\hline 4 & National & $\begin{array}{c}\text { National/ } \\
\text { Site } \\
\end{array}$ & National & $\begin{array}{c}\text { National } \\
\text { nZEB }\end{array}$ & $\begin{array}{c}\text { National } \\
\text { nZEB }\end{array}$ & National & National nZEB \\
\hline 5 & Simulation & National & National & $\begin{array}{l}\text { National } \\
\text { reference }\end{array}$ & $\begin{array}{l}\text { National } \\
\text { reference }\end{array}$ & $\begin{array}{l}\text { National } \\
\text { reference }\end{array}$ & $\begin{array}{c}\text { Nat. reference } \\
\text { building }\end{array}$ \\
\hline 6 & Simulation & $\begin{array}{c}\text { National/ } \\
\text { Site }\end{array}$ & National & $\begin{array}{c}\text { National } \\
\text { nZEB }\end{array}$ & $\begin{array}{c}\text { National } \\
\text { nZEB }\end{array}$ & National & National nZEB \\
\hline 7 & Simulation & $\begin{array}{l}\text { National/ } \\
\text { Site }\end{array}$ & Framework & $\begin{array}{c}\text { National } \\
\text { nZEB }\end{array}$ & $\begin{array}{c}\text { National } \\
\text { nZEB }\end{array}$ & National & $\begin{array}{c}\text { Comparison } \\
\text { to No.2 / No. } 11\end{array}$ \\
\hline 8 & Simulation & Strasbourg & Framework & $\begin{array}{c}\text { National } \\
\text { nZEB }\end{array}$ & $\begin{array}{c}\text { National } \\
\text { nZEB }\end{array}$ & National & Comparison to No.1 \\
\hline 9 & PHPP & $\begin{array}{c}\text { National/ } \\
\text { Site }\end{array}$ & Framework & PH envelope & $\begin{array}{c}\text { Ideal heating } \\
20^{\circ} \mathrm{C}\end{array}$ & - & PHPP PH \\
\hline 10 & Simulation & $\begin{array}{c}\text { National/ } \\
\text { Site }\end{array}$ & Framework & PH envelope & $\begin{array}{l}\text { Ideal op. } \\
\text { temp. } 20^{\circ} \mathrm{C}\end{array}$ & - & PHPP PH \\
\hline 11 & Simulation & $\begin{array}{c}\text { National/ } \\
\text { Site }\end{array}$ & Framework & PH envelope & Framework & Framework & $\begin{array}{c}\text { National PH } \\
\text { Comp. to No. } \\
\end{array}$ \\
\hline
\end{tabular}

Legend: Framework - Reference framework based on Dott et al. (2013), national - based on national nZEB rating procedure (tool), national reference - based on a national reference building defined by some national building regulations for $n Z E B$ rating, national $n Z E B$ - framework building with modified parameters that fulfill the national minimum requirements for $n Z E B$ rating tool: national calculation tool used for nZEB rating on the national level, simulation - simulation program used for the evaluation of energy consumption and performance. PHPP - passive house projecting package, $\mathrm{PH}$-passive house.

\section{Steps of the methodology - Step 3-8: National case}

Step 3-8 are denoted as national case and consist of transforming the reference framework building to national boundary conditions (BC) which exactly fulfil the nZEB requirements in the country and back to common boundary conditions and climate data of the reference building.

Thus, in step $3 / 4$ the reference framework is modelled in the national calculation tool, often Excel based, which is used to prove compliance with the national nZEB requirements. Thereby, all boundary conditions have to be set to national values, i.e. tapping demands and internal loads, since the national nZEB requirements are defined by national calculation methods and values. In the national calculation tool, parameters of the framework building are modified until the building exactly meets the limit to comply with the national nZEB requirements. Depending on the national calculation, this may also include HVAC in terms of heat pump performance, control settings, ventilation or different shading levels. Step 3 is relevant for countries, which use a national reference building in order to define the national requirements like in the German EnEV 2016/KfW55 and the Austrian OIB directive 6. For instance, the average heat transfer $\mathrm{H}_{\mathrm{T}}$ of the reference building in the German EnEV is maximum $0.4 \mathrm{~W} /\left(\mathrm{m}^{2} \mathrm{~K}\right)$ for a detached dwelling with $A_{N}<350 \mathrm{~m}^{2}$, so the building to be certified shall meet this values or fall below it.
In step 5/6 the building, HVAC and renewable parameters are transferred from the national tool to the simulation program, in case of a national reference building, both for the reference building (Step 5) and the national nZEB (Step 6). By the simulation tool, the calculation method is normalised from different national calculation approaches to a common calculation based on the simulation model. Remaining differences between the results of the national calculation tool and the simulation shall be documented, but no detailed calibration is done for the simulation model, since the more detailed simulation necessarily delivers different results. As further normalisation, in step $7 / 8$ boundary conditions are changed back to the framework. This is done for the internal loads, tapping demands and indoor temperature set points. For the weather data, evaluations may be performed both in national weather conditions (Step 7) and for the common Strasbourg weather of the framework (Step 8). Then, the simulation is performed and the data are compared to the results of the calibration or climate case, respectively, which thereby serves as reference for the comparison of the ambition levels. In order to avoid distortion of different primary energy factors and different national energy reference area definitions, the absolute electric energy input for the HVAC in terms of space heating, DHW production and ventilation is compared, since cooling/air-conditioning is not needed in the climate zone. This is valid for all-electric buildings. In future work, additional energy carriers will be considered, too. 


\section{Steps of the methodology - Step 9-11: Passive house}

As variant, also the reference building of an ultra-low energy house in terms of the internationally widespread passive house label is investigated.

The approval of the passive house compliance is done by the planning tool Passive House Projecting Package (PHPP), www.passiv.de. Thus, the implementation of the passive house starts with the adaption of building parameters in order to comply with requirements in the PHPP. Since a passive house is mainly defined by the heating demand of $15 \mathrm{kWh} /\left(\mathrm{m}^{2} \mathrm{a}\right)$, the building envelope parameters are adapted. Boundary conditions in term of internal loads are taken from the reference framework (step 9), but the PHPP calculates the heat load for ideal heating to $20{ }^{\circ} \mathrm{C}$. In step 10 and step 11 , the transfer to the simulation programs is performed like in step $7 / 8$. For the passive house, only the national weather has been considered, i.e. the passive house serves as a local reference with high ambition level. Thereby, in order to compare the simulation, the indoor temperature is controlled to $20{ }^{\circ} \mathrm{C}$ operative temperature in step 10 , while in step 11, the HVAC and boundary conditions of the framework are applied.

The evaluation of the ambition level is made on the national level in terms of the difference to the high ambition level of the passive house as common baseline. The relative difference among the countries to the local passive house serves as indicator for the ranking of national ambition levels.

\section{Results}

The results are illustrated for the calibration case (step 1) in order to conclude on different applied simulation programs and the national case representing the national nZEB implementation. The climate case (step 2) yields an evaluation of climate impact among the sites.

\section{Results of the calibration case}

As first step, the methodology includes a calibration of the different simulation programs used in the investigation. This is motivated by the differences due to the use of different simulation programs. Figure 2 shows the comparison of heating demand for the reference framework building after different improvement steps.

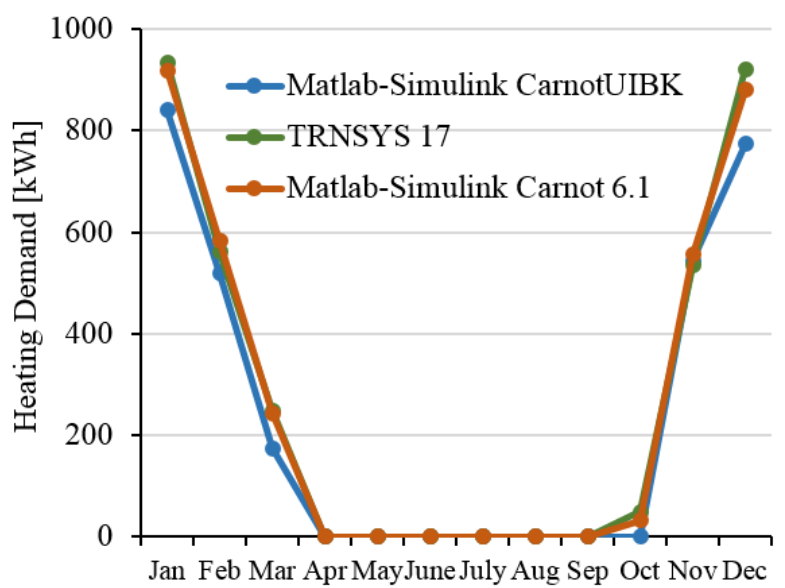

Figure 2: Comparison of space heating demand for the calibration case (step 1).
Remaining annual differences between TRNSYS and the two implementations in MATLAB-Simulink with the Carnot Toolbox 6.1 (2017) and the CarnotUIBK Toolbox (2019) are at maximum $10 \%$ in December and are due to different modelling approaches in the different programs. Figure 3 shows the monthly average operative temperature as indicator for the thermal indoor environment.

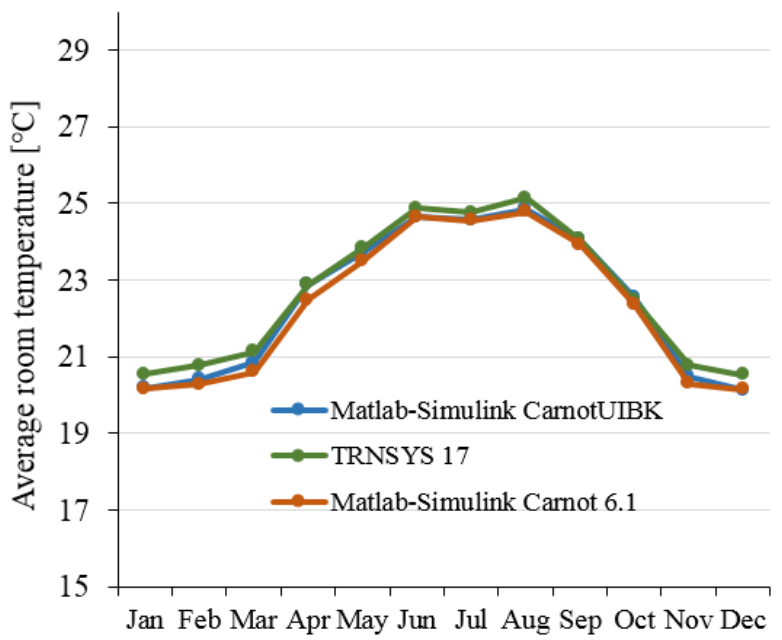

Figure 3: Monthly averaged operative temperature.

In the space heating operation of the winter months the temperatures are very close for all programs, i.e. in the winter month Nov. - Feb., all operative temperatures are in the range of $20.1-20.8^{\circ} \mathrm{C}$. The maximum deviation in the single month in the range of $0.16 \mathrm{~K}$ to $0.25 \mathrm{~K}$ from the average, so the space heating operation yields basically the same room temperatures.

Figure 4 depicts the delivered energy in terms of absolute electric energy for the whole building technology also including DHW and ventilation. Difference among the programs are even smaller due to the seasonal performance factor of the heat pump, so for the following comparisons of national nZEB implementation, a good starting point is assured by the calibration case both for the system boundary of used space heating energy and delivered electrical energy.

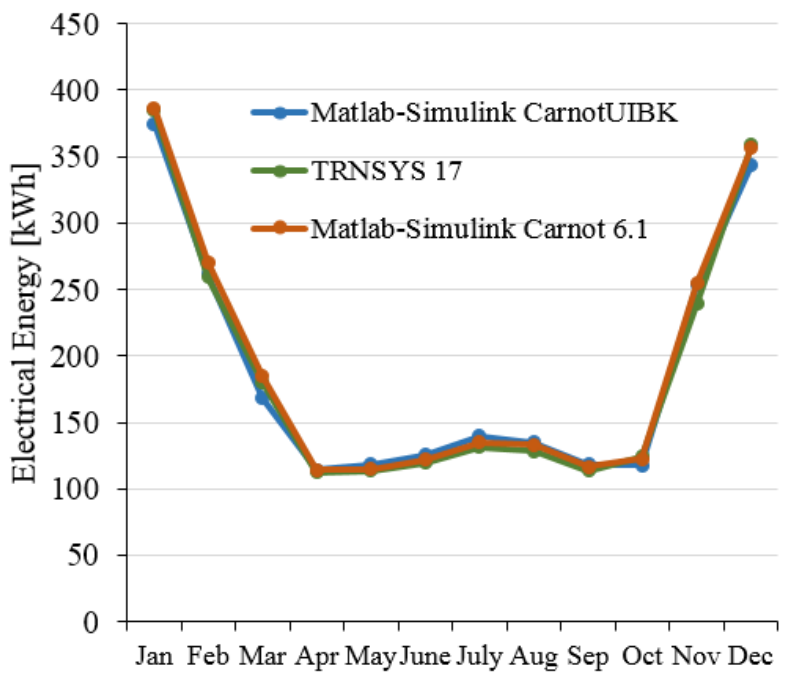

Figure 4: Comparison of electrical energies for the calibration case (step 1). 


\section{Results of the climate case}

As step 2, the methodology contains a change to national weather data in order to characterise changes in the building energy demand dependent on the climate. All other building parameters are kept. Here, the three sites Innsbruck, AT, Potsdam, DE and Zurich, $\mathrm{CH}$ are considered based on the following national calculation procedure performed in step 3-8.

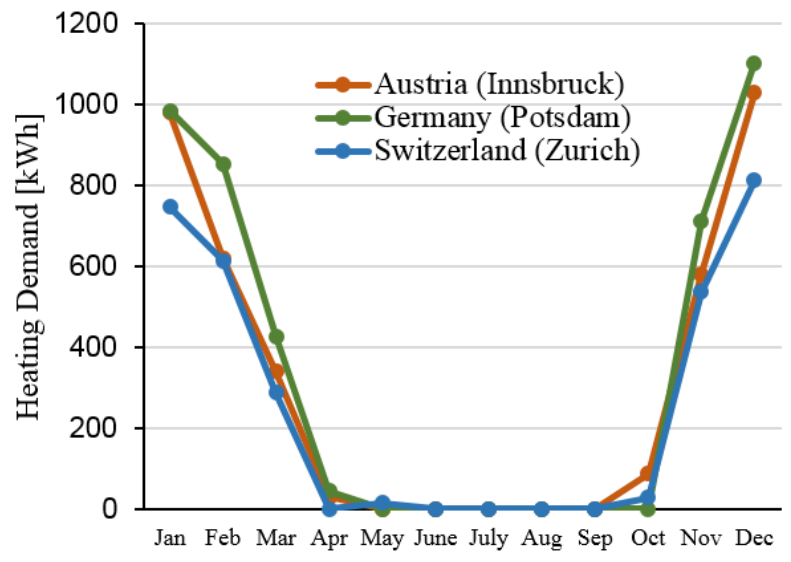

Figure 5: Comparison of space heating demand for the climate case.

The comparison depicted in Figure 5 shows, that the Innsbruck and Potsdam weather cause similar annual shift in space heating demand, with a higher space heating demand in February and March at Potsdam, while the Zurich weather is less severe in wintertime and thus the space heating demand is lower. Despite the differences, the basic climate is similar among the different sites, thus building layout will not vary much based on the climate and a shift to the common framework climate is feasible.

\section{National case with reference framework baseline}

In step 3-8 denoted as national case, the results comprise the comparison of the nZEB in the single countries based on the reference framework building in Strasbourg, i.e. step 1 (framework) and step 8 (national nZEB) are compared. Therefore, after modifying the building and HVAC parameters to meet the national requirements of the rating procedure (step $3-6$ ), the framework boundary conditions (step 7) and the weather data of Strasbourg (step 8) are applied to the national nZEB. Figure 6 depicts the heating demand for this case for Germany, Austria and Switzerland. The energy is given in absolute values in $[\mathrm{kWh}]$ in order to prevent distortion by different national reference area definitions. The comparison is based on the respective national building regulations for the implementation of nZEB, in Austria the OIB directive 6 and in Switzerland the MuKEn 2014. For Germany, the more ambitious KfW 55 compared to EnEV 2016 has been used. As stated above requirements set by the national building directives are different and calculation methods and boundary conditions also differ. For instance, as mentioned above, Germany and Austria use a reference building, while in Switzerland, limits for the building envelope and the weighted delivered energy depending on the building usage are set.

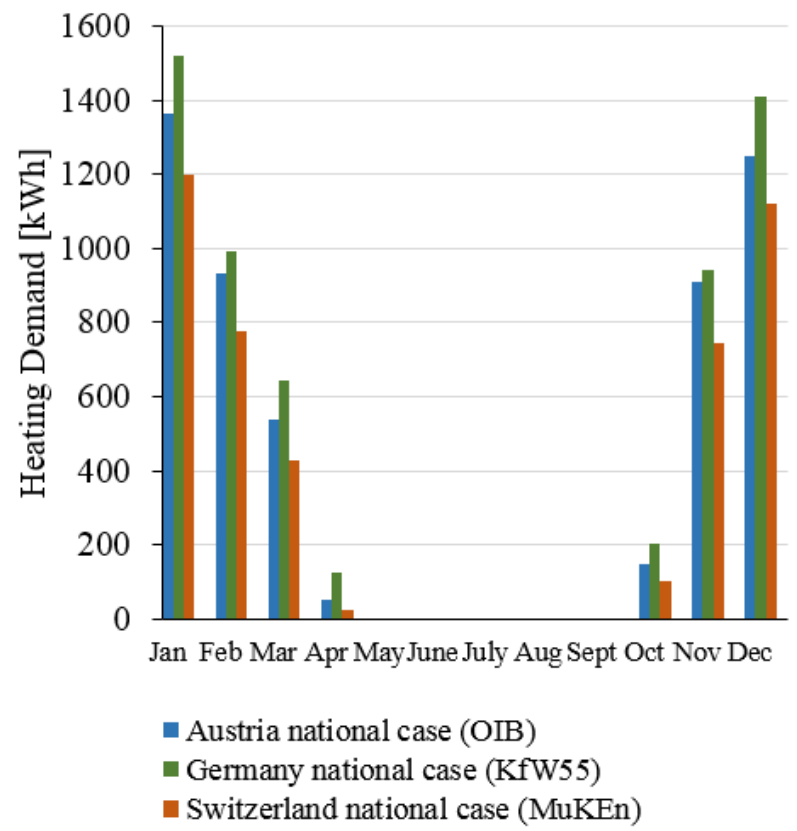

Figure 6: Comparison of heating demand in Strasbourg (step 1 compared to step 8).

The comparison of space heating demands in Figure 6 characterising the building envelope shows that the Swiss nZEB requirement is the strictest, while the German and Austrian requirements are less ambitious. However, the nZEB concept is related to the balance of building envelope and the HVAC system, so also the delivered energy for the HVAC functions is compared in Figure 7, which is mainly affected by the heat pump operation.

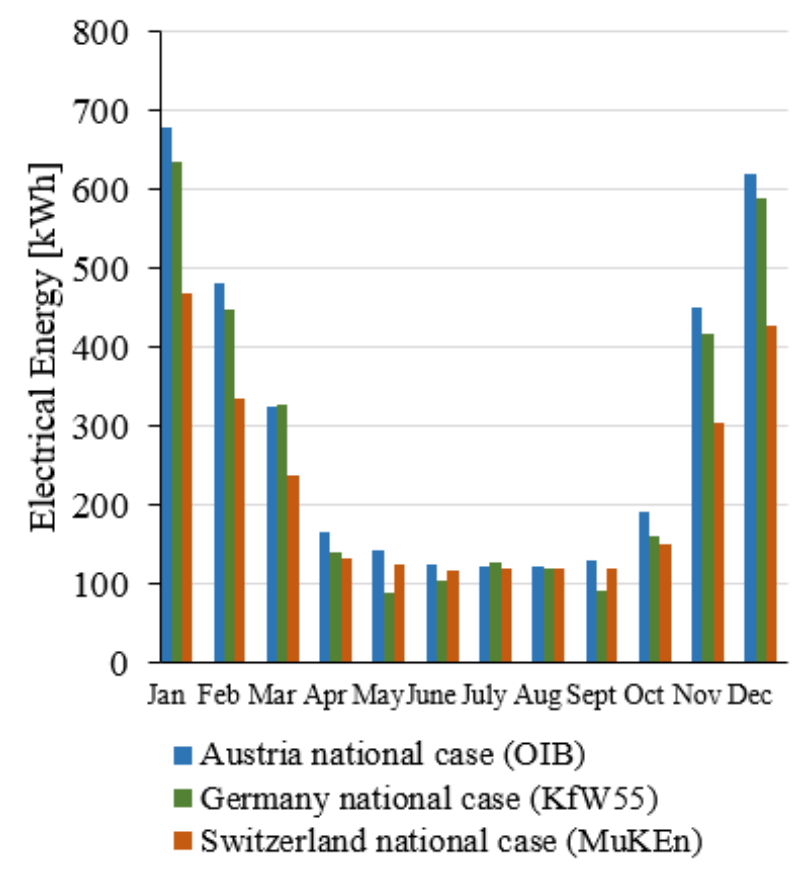

Figure 7: Comparison of absolute electrical energy demand in Strasbourg (step 1 compared to step 8).

Table 2 shows the differences of used energy for space heating among the countries and as percentaged deviation from the reference framework. 
Table 2: Comparison of heating demand.

\begin{tabular}{|l|c|c|c|c|}
\hline & RF & AT & CH & DE \\
\hline Energy [kWh] & 3128 & 5792 & 3551 & 4828 \\
\hline$\Delta$ to RF [\%] & 0 & +46 & +14 & +35 \\
\hline
\end{tabular}

Legend: $R F$ - reference framework

Annual differences among the national nZEB buildings and the reference framework are also shown in Table 3. In this case the comparison in terms of used energy and delivered energy yields the same order, although it can be seen by the ratio between used energy and delivered energy, that in Germany a focus is set on the overall energy balance instead of the building envelope, since the higher ratio indicates that higher used energy demand is compensated by more efficient HVAC technology. In Austria, in contrary, the ratio is lower, i.e. the focus is more on the building envelope and the HVAC performance is lower. Switzerland is in-between these two.

Table 3: Comparison of absolute delivered energy.

\begin{tabular}{|l|c|c|c|c|}
\hline & RF & AT & CH & DE \\
\hline Energy [kWh] & 2258 & 3658 & 2652 & 3242 \\
\hline$\Delta$ to RF [\%] & 0 & +55 & +16 & +42 \\
\hline Ratio HD to DE & & 1.46 & 1.65 & 1.8 \\
\hline
\end{tabular}

Legend: $H D$ - heating demand, DE - delivered energy

For the complete picture, though, also the renewable energy generation on-site would have to be taken into account, e.g. in terms of PV production. In fact, the Swiss building regulation contains a requirement for a PV installation rate depending on the reference area of the building. However, these aspects have not been considered in this paper and are a topic for further evaluation.

\section{National case with passive house reference baseline}

As described in steps 9-11 also a comparison to a passive house in local climate has been evaluated.

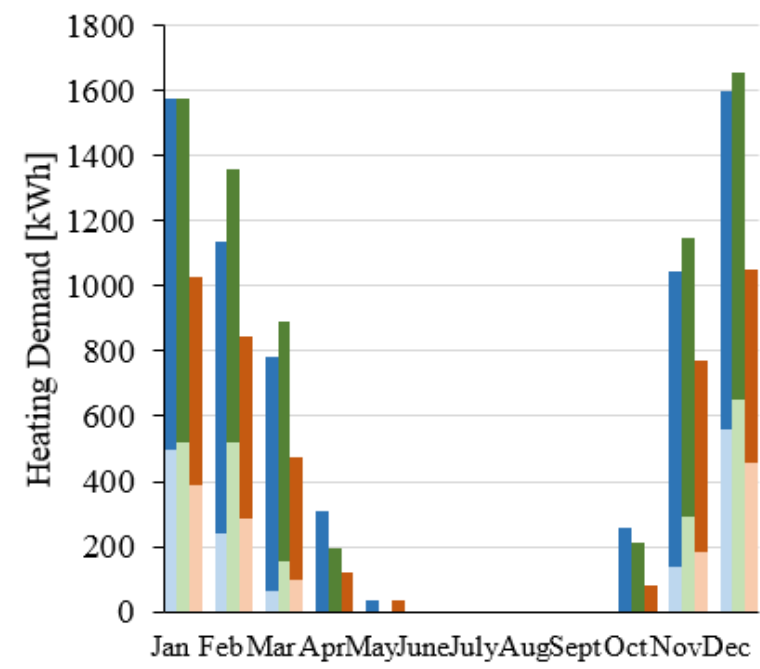

- Switzerland national case (MuKEn 2014)/passive house

- Germany national case (KfW55)/passive house

- Austria national case (OIB)/passive house

Figure 8: Comparison of space heating demand for

baseline passive house (step 11 and step 7).
This is motivated by a comparison between different climate zones, so for this comparison a high performance building with high ambition level at local climate conditions is chosen as reference. Here, the internationally widespread Passive House standard is taken as reference building and national weather data is used. The criteria evaluated is again the used energy to cover the space heating demand and delivered electrical energy for HVAC operation of the national nZEB compared to the local Passive House (step 11 and step 7). Results are shown in Figure 8 for the heating demand and in Figure 9 for the delivered energy.

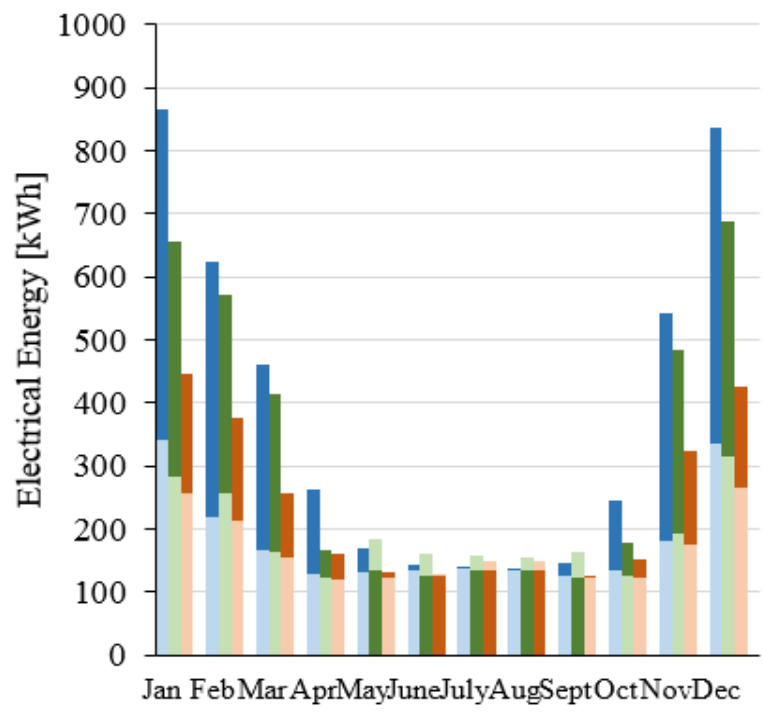

- Switzerland national case (MuKEn 2014)/passive house

- Germany national case (KfW55)/passive house

- Austria national case (OIB)/passive house

Figure 9: Comparison of electrical energy for baseline passive house (step 11 and step 7).

For Switzerland the national nZEB is compared with the Swiss Passive House at the site Zurich (weather data set Zurich Meteoschweiz), for Germany the KfW55 requirement is compared with the Passive House at the site of Potsdam and for Austria, the national nZEB according to OIB directive 6 (2015) and the Passive House at the site of Innsbruck are considered.

Table 4: Comparison of absolute delivered energy between national $n Z E B$ and passive house (Step 7 compared to Step 11).

\begin{tabular}{|l|c|c|c|}
\hline & AT & CH & DE \\
\hline Energy nZEB [kWh] & 4573 & 2766 & 3647 \\
\hline Energy PH & 2171 & 1953 & 2116 \\
\hline$\Delta$ to PH [\%] & +111 & +29 & +42 \\
\hline Ratio HD to DE & 1.5 & 1.6 & 1.9 \\
\hline
\end{tabular}

Legend: $P H$ - passive house, $H D$ - heating demand, DE delivered energy.

Absolute electrical energy values for space heating and DHW and the differences to the passive house electrical energy are given in Table 4. 
As expected by the former case, the relative ranking is the same as for the framework baseline. However, by the different climate data, the absolute numbers shift compared to the common climate for all three buildings and due to the high energy performance or ambition level of the passive house, respectively, differences to the passive house in the local climate become more pronounced and obvious. In addition, in this case, for a complete assessment, the renewable on-site production would have to be taken into account, which is also linked to local climate conditions at the site and may differ even in the same climate zone, but more district among climate zones. This is an objective for future evaluations.

\section{Discussion}

The methodology presented allows a relative comparison of the different ambition levels of the countries regarding the national implementation of the EPBD based on a reference building. Thereby, an indication is given, in how far the implementation of the EPBD recast will contribute to an increase of the energy performance in the new built sector. The comparison is useful for policy makers in order to evaluate the degree of implementation of the EPBD requirements and to set out stricter targets for the future implementations of the EPBD. Moreover, less ambitious countries can be approached in order to demonstrate the gap among countries and encourage them regarding the transition to a higher ambition level.

Besides the different definition of nZEB among the EU member states, the ambition level of the national nZEB are also affected by the national calculation method, the calculation tool itself, the boundary conditions and the climate. In the methodology, the different steps aim to normalise these impacts by a common reference. For the evaluation based on the reference framework building at Strasbourg weather, boundary conditions are set equal and calculation methods and tools are calibrated to minimise differences.

Thus, the only remaining impact is the national building envelope, HVAC and renewables derived by the respective nZEB requirements in the countries. However, a limitation of the methodology occurs, if different climate zones are considered. For instance, a building in a cooling dominated climate, e.g. in Rome is not optimised for the space heating operation, since the needs are rather low compared to central European climate, and if transferred to a colder climate, the performance characterisation will be limited by that. Moreover, the national requirements may have been particularly adapted to the local climate conditions. Therefore, a second evaluation has been considered using local climate data, which are calibrated by a local reference.

In this case, a passive house has been chosen as internationally widespread building standard. Again, boundary conditions are equalised by common ones. Thereby, the evaluation in different climate zones is possible, but there is still a remaining climate impacts due to the use of the local climate.

In Ahmed et al. (2018), an approach for a climate correction based on a change to economic insulation levels linked to a correction with heating degree-days is considered for an office building with high glazing fraction. This approach shall be investigated also for residential buildings, which may have higher heating demand than the office building.

Experiences from the calibration case shows that the use of different simulation programs complicate the comparison. Even with a detailed description of the reference framework building, which is a rather simple building, and different steps of calibrations, remaining deviation among the TRNSYS and Matlab-Simulink Carnot variants range up to $10 \%$ in single month. Thus, a calibration is an absolute necessity before a comparison can be made when applying different simulation programs.

\section{Conclusions}

By January 1, 2019, the definite implementation of the EPBD recast of 2010 has started in the European Member States due to the requirement that all new public buildings have to comply with the nZEB requirement. As already could be concluded before the deadline resulting nZEB definitions in the EU MS strongly vary in criteria, metrics, system boundaries and limits. However, both for policy makers and for the building and system technology industry it would be useful to compare ambition levels in the different countries to motivate less ambitious countries to catch-up with more ambitious countries and to develop high performance standardized system technology for respective ambition level by the internationally operating system manufacturers, which are acting in the different national markets.

In this paper a methodology to compare the ambition level based on building and system simulations is presented, which allows the assessment of a relative order of ambition levels in the different countries based on a reference building in a reference climate. The method has been applied for the countries Austria, Germany and Switzerland.

By the application of the methodology, it is confirmed that due to the different introduced nZEB definitions a comparison of the ambition levels is a complex procedure. Besides the varying definitions, the comparison is further hindered by the different calculation methods and boundary conditions to prove compliance with the nZEB requirement.

Last but not least, also the different simulation programs used for the comparison impede an easy comparison. Even for a well-documented building and standard simulation tools different calibration steps have been included and even remaining deviation of the heating demand are in the range up to $10 \%$ in single month. Thus, there is a necessity for a calibration step when using different programs.

Since no explicit climate correction is applied, but the different national boundary conditions are equalised by a reference building with reference boundary conditions at a reference site, it is hard to compare different climate zones. A solution could be a local reference building in the national reference climate and an internationally introduced reference ambition level like a Passive House, which has reached a wide international acceptance and is 
widely spread across European countries and worldwide. The ambition level would then be evaluated as relative difference to the passive house at the same national site.

The methodology presented is still work in progress and further developments of the method by future evaluation is planned. On the one hand, evaluations in this publication focuses on the building envelope, while nZEB include also the energy generation aspect, mostly in terms of solar PV production. In this sense, also different load characteristic and different building types should be investigated, e.g. a multi-family-building and the renewable energy production on-site is another evaluation criterion not considered in this paper. Moreover, further evaluations regarding climate corrections, e.g. based on HDD as applied in Ahmed et al. (2018) is planned for the future. Moreover, a broader comparison of more countries could give a deeper understanding of the EPBD implementation across European member states. Regarding simulation tools, also further comparisons with IDA-ICE (2019) are planned.

\section{Acknowledgements}

The effort and feedback of the participants of IEA HPT Annex 49 during the development of the methodology is highly acknowledged.

Gratitude and acknowledgment is also expressed for the support and funding of the Swiss Federal Office of Energy of the IEA HPT Annex 49 international research collaboration.

\section{References}

Ahmed, K.; Carlier, M.; Feldmann, C.; Kurnitski, J. (2018). A New Method for Contrasting Energy Performance and Near-Zero Energy Building Requirements in Different Climates and Countries. Energies, 11 (6), 1-22.

BPIE (2015). Nearly Zero Energy Building definitions Across Europe, Factsheet. Brussels.

Conference of cantonal energy directors (2015). Model ordinance of the cantons in the field of energy (MuKEn), edition 2014, 9. Jan. 2015, Berne.

Dott, R., Haller, M. Y., Ruschenburg, J., Ochs, F., Bony, J. (2013). The Reference Framework for System Simulations of the IEA SHC Task 44 / HPP Annex 38 - Part B: Buildings and Space Heat Load. Institute of Energy in Building, FHNW, Muttenz.
EnEV (2017). Energy saving ordinance on energy saving thermal insulation and energy saving system technology in buildings, Berlin.

European Parliament (2010). Directive 2010/31/EU of the European Parliament and Council of May 19, 2010 on the energy performance of buildings (recast), Journal of the European Union, L 153/13.

IEA TCP (2013). IEA SHC Task 40 EBC Annex 52 Towards Net Zero Energy Solar Buildings, Oct. 2008 to Sep. 2013.

Equa Simulation AB (2019). IDA-ICE 4.8, Stockholm.

International Organisation for Standardisation (2017). Energy performance of buildings-Overarching EPB assessment -- Part 1: General framework and procedures (ISO 52000-1:2017).

IPEEC Building Energy Efficiency Taskgroup (2018). Zero Energy Building Definitions and Policy Activity - An International Review, Paris.

JRC science for Policy (2016). Synthesis report on the national plans for nearly Zero Energy Buildings (NZEBs), Ispra.

KfW (2019). Efficiency house 55, Fact sheet energy efficient building, Kreditanstalt für Wiederaufbau, Frankfurt am Main.

Kurnitski, J. (Editor) (2013). REHVA nZEB technical definition and system boundaries for nearly zero energy buildings, 2013 revision for uniformed national implementation of EPBD recast prepared in cooperation with European standardization organization CEN, REHVA report No 4, Federation of Heating, Ventilation and Air Conditioning Associations, Brussels.

MathWorks (2017). Matlab-Simulink, Release 2017 a, Massachusetts.

OIB Directive 6 (2015). Energy saving and thermal insulation, Austrian Institute of Building Technology, Vienna

Siegele, D., Leonardi, E. and Ochs, F. (2019). A New MATLAB Simulink Toolbox for Dynamic Building Simulation with B.I.M. and Hardware in the Loop Compatibility. In Building Simulation. Rome, Italy: IBPSA

Solar Energy Laboratory (2017). TRNSYS, version 17, University of Wisconsin-Madison 